\title{
Racist and Neo-Nazi Panic in the Euro 2012 Coverage by the British Press: A Discursive FAILURE IN INTERCULTURALISM
}

\begin{abstract}
The article demonstrates how the discursive strategies of sport reporting by the media may collide with the vision of sport as a means of promoting intercultural understanding, a generally anticipated cultural effect of mega sport events. This is done by a critical discourse reading of 35 news articles that appeared across the British national press in May and June 2012, directly before the opening of the $14^{\text {th }}$ UEFA European Football Championship (Euro 2012) jointly hosted by Poland and Ukraine. Influenced by a BBC television documentary and linked by the central topic of the two countries as strongholds of racism, xenophobia and vicious hooliganism, these articles constitute an instance of a moral panic. A discussion of the panic as a mode of discourse leads to the conclusion that the priorities and practices of British newspaper journalism acted against the culturally integrating potential of Euro $2012{ }^{1}$
\end{abstract}

\section{Key words}

Press scare; moral panic; mediated sports; interculturalism; discourse analysis; Euro 2012; British press; Eastern Europe

\section{Introduction}

From 8 June to 1 July 2012 Poland and Ukraine jointly hosted the UEFA European Championship, commonly referred to as Euro 2012. Both countries hoped the mega sport event would generate tourism gains and boost economic growth in the long run. Equally important was the anticipation of intangible benefits: gaining media exposure, promotion as inviting tourist destinations and sending 
signals to the rest of Europe about their openness, safety and attractiveness. Little did they expect a surge of articles like those in the British press in the pre-event weeks reporting the alleged danger of racist violence and neo-Nazi hooliganism threatening the footballers and their fans in Poland and Ukraine.

Like many historical and contemporary sporting mega-events, particularly the Olympic Games, football Euros and World Cups, Euro 2012 has by now a scholarly literature of its own in several fields. Sport sociologists, political scientists, government analysts, cultural critics, economists and even a lawyer have examined the championships from several angles and perspectives, applying different methodologies. They explored the connections between Euro 2012 and various international and domestic political tensions, examined the Euro as a context for articulating national identities and interpreted the symbolism of the national football emblems. Others investigated the attractiveness of Polish football clubs on Europe's football job market, or recommended the adoption of specific legal restrictions to curb football violence in Eastern Europe. Polish international relations experts evaluated the Euro as an exercise in country/nation branding in the international arena (Wizor 2012; Ciołkiewicz 2012; Watson 2013; Dembek and Włoch 2014; Kennedy and Kassimeris 2014). Little analytical work has been done so far on the coverage the tournament received in foreign media (Mazur and Wawrzyczek 2016).

Another body of scholarship informing the present article belongs to the dynamically developing field of Intercultural Studies. Amidst the ongoing attempts at the refinement of its central concept of interculturality (Lavanchy, Gajardo and Dervin 2011: 1-28; Rozbicki 2015: 1-5), the generally undisputed working definition of intercultural engagement involves "penetration of the Other's cultural system: getting out of oneself to see things from the Other's perspective," "an attitude of opening up, a personal effort of inquiry" accompanied by the ability of negotiating the differences ("Interculturality"). International sport events, both at the participatory and spectacle levels, inevitably confront people with cultural otherness and generate dynamic responses to the difference in the process of interaction. Therefore the role of sports as space for intercultural dialogue has long been recognized in Europe, and the EU social policymakers constantly emphasize its significance as a tool for cultural integration (Sharing Diversity 2008; Gasparini and Cometti, 2010). Recent publications also deal with the culturally integrating effects of sports from different angles (Müller et al 2008; Rosner et al 2010; Garriado et al 2012; Merkel 2014).

However, while political and educational initiatives are taken up to dispose individuals and societies towards intercultural dialogue - for instance the year 2008 as the Year of Intercultural Dialogue in the European Union, the media often remain oblivious to this goal, also in sport reporting. On the one hand, the media spend a great deal of their resources on sports; newspapers dedicate special sections to sport news and commentary, they employ large numbers of sports columnists and reporters, and sports programming constitutes a substantial part of television and radio networks as well as of various online media formats (Wenner 
1998; Raney and Bryant 2006; Billings and Hardin 2014). Yet, academic research on mediated sports in today's world points to the perpetuation of nationalism, social stratifications and cultural prejudices by various forms of "othering" in sports reporting and representations of athletes (Bishop and Jaworski 2003; Wensing and Bruce 2003; Bruce, 2004; Dimeo and Kay 2004; Hardin et al 2004; Maguire et al 2009; Inthorn 2010; Hammett 2011; Mishra 2012; Bruce 2015).

This analytical essay, situated at the intersection of media and cultural studies, focuses on the cultural dimension of Euro 2012 and argues that the British news media undermined the tournament's potential to promote intercultural engagement among its international participants and observers. The case study in support of the thesis involves reporting Poland and Ukraine as the joint hosts of Euro 2012 by the British national press during ten pre-event days between 27 May and 5 June 2012. What happened then was an eruption of classical scare journalism injecting fear into the readers, many of whom could have been football fans planning trips to the matches. The overall effect was that of moral panic and hysterical visions of danger allegedly facing the fans in Poland and Ukraine due to vicious neo-Nazism and racism. By assuming the role of moral vigilantes and civil liberties protectors, British national newspapers seriously undercut the chance for a popular European mega sport event to become a culturally integrating and peacemaking occasion. Acting according to a certain established concept of the socio-cultural order in Europe and their own circulation concerns, the media reinforced negative stereotypes of Eastern Europeans and missed the opportunity to bridge the cultural gap between Eastern and Western Europe.

Most recently a broad analytical and conceptual perspective on "othering" practices in today's media has been offered by Molek-Kozakowska and Chovanec (2017: 1), who "highlight the role of the national media in European public spheres in sustaining, but also reconstructing, collective identities" and focus on the concepts of "the other" and othering in their discursive functions of differentiation and discrimination. The present study seems to fit well into this framework as the discussed case of moral panic is in fact a journalistic form of discursive othering. It also goes further by pointing out that such othering is a contradiction of interculturality.

\section{Material and method}

The corpus of texts classified as parts of the 10-day panic was obtained while searching online editions of British national dailies and Sundays on the LexisNexis Academic full text newspaper database from the period covering one year before Euro 2012, the duration of the event and one month afterwards, that is between June 2011 and July 2012. The search was performed with the keywords Euro 2012/Poland/Polish/Ukraine/Ukrainian. The newspapers of national circulation were chosen as most influential and enjoying wide readership, paper and online, not only in the UK but also globally. Each article was counted once; identical 
or almost identical articles appearing in regional editions and in daily online updates of the same paper were eliminated. Given these selection criteria, 35 news stories and reports of various length (104 to 1797 words, 500-700 average) from 10 national quality and tabloid newspapers, all accessed and downloaded from the database from 3 to 6 June 2013, were included in the final analysis. They appeared in various paper sections, mostly on sport pages and their football subsections (22), in the international and home news sections (11) and in other places (2).

The analytical procedure applied to the news material was a combination of the well-established research methods of media content and discourse analysis, supplemented by narrative analysis. Quantitative content analysis served the purpose of identifying the dominant and satellite themes, the occurrence of which was not statistically analysed and intercoder reliability was not assessed due to the small text corpus under scrutiny (Neuendorf 2002; Riffe et al 2014). Several quotes included in the analysis below provide examples of the dominant narratives. Subsequently, critical discourse analysis was applied to the study sample to determine the linguistic devices employed by the newsmakers and to conclude about their ideological effect (Bell 1991; Fowler 1991; van Dijk 1988, 2001; Wodak and Meyer 2006; Conboy 2007; van Leeuven 2008; Fairclough 2013; Bednarek and Caple 2012a, 2014). As the LexisNexis database does not retain the newspaper visuals, such as photographs, typography, colour and the original layout, the analysis was limited to the modalities of verbal texts. The ultimate purpose was to determine a set of beliefs about and attitudes towards the Euro 2012 host societies foregrounded in the studied material.

Scare tactics - a strategy using fear to influence the public's reaction - crept into journalism long ago and is by now well-recognized in mass communication. The feared object/subject becomes exaggerated in excess to the events which caused it, and quickly acquires autonomous existence as a specific type of discourse characterized by repetition, often in the form of a vicious circle, to reinforce the intended effect. A typical rhetorical device is the high emotive level achieved by the vocabulary of hazard and crisis. Journalistic fearmongering also tends to throw the spotlight on various institutions, groups and individuals to undermine their reliability and effectiveness, to blame and hold responsible - depending. "Ordinary people" interviewed by journalists serve the purpose of keeping fear alive by giving first hand evidence of scary situations. The main theme is often accompanied by satellite topics selected for their potential to build up the atmosphere of alarm (van Dijk 1988; Fowler 1991: 146-207; Brookes 1999; Cohen 2002; Marsh and Melville 2011; Howarth, 2013). The articles were closeread for the presence of journalistic tactics fitting this description.

Moral panic, one of the key concepts in the present study, has a rich multidisciplinary literature of its own, impossible to review here comprehensively. In the study on the social construction and diffusion of fear, Goode and BenYehuda (2009: 2) define moral panic as "a scare about a threat or supposed threat from deviants ... who, presumably, engage in evil practices and are blamed for 
menacing a society's culture, way of life, and central values". The concept has been applied in numerous studies of the media reaction to many social problems, including football hooliganism. The media analysts von der Lippe and MacLean (2008: 74), in their study of the media panic during the 1954 football World Cup, proposed to treat football moral panics as a "code for ideology" connected to "an implied and assumed national-cultural, and racialized, hierarchy." Their perspective was particularly inspiring for the present study and the interpretation of its results.

Although the press articles under scrutiny were not specifically studied for their news value, their high newsworthiness cannot be overlooked. While it could be explained in terms of the classic twelve factors that determine the news value of an event drawn by Galtung and Ruge (1965), with several subsequent modifications (Schulz 1982; Bell 1991: 156-160; Harcup and O'Neill 2001; McGregor 2002; Shoemaker and Cohen 2006: 7-21, 335-354), it is the constructivist approach of Bednarek and Caple $(2012 \mathrm{a}: 39-83$; 2014) that enables a deeper cultural insight into the moral panic in question. Assuming, after these authors, that newsworthiness is not an inherent attribute of events but the effect of their journalistic production through language and image, one can treat news as a symbolic reflection of the culture in which it is constructed and circulated. Thus, the linguistic devices identified in the scare reporting of Poland and Ukraine by the British press just before the approaching Euro football tournament constitute tangible evidence of pre-existing British conceptions of these countries.

\section{The context of the press scare in the build-up to Euro 2012}

Some concern about ill-famed football hooliganism in the Euro 2012 host countries surfaced briefly in the British press already in 2007, a day after the PolandUkraine bid to host the championship was chosen by a vote of the UEFA Executive Committee at the meeting in Cardiff on 18 April that year. Nick Szczepanik of The Times reported in a longer and generally optimistic article about the newly elected hosts that while the rivalries between some Polish football clubs "have been the cause of violent clashes over many seasons, it appears that, in most cases, those tendencies do not carry over on to the international stage." He was concerned about "the racist elements among football supporters in Eastern Europe, although progress appears to have been made on that front." ${ }^{2}$ Another occasion for raising the topic of hooliganism and racism in Polish football appeared in October 2011, when Michel Platini visited both host countries to inspect the football stadia. The Telegraph reported alarmingly that "the government crackdown on football fans is a smokescreen" and that "[n]ot even the staunchest defender of civil liberties could deny that Poland still has a hooliganism problem." Although spectacular incidents of football violence were mentioned, such as the case of a hooligan leader in Krakow being hacked to death by rival fans, the article ended on a reassuring note about security preparations in Poland and Ukraine. ${ }^{3}$ 
Despite occasional comments and concerns of this kind, no evidence was found in the studied press of excessive preoccupation with football hooliganism and racism in the Euro 2012 host countries until quite close to the event, when it was brought into focus by British television. First, on 15 May 2012, Sky Sports News showed the video "Ukraine's Hidden Hooligans" in their Special Report. It uncovered a scary culture of the Donbas Football Club Shakhtar Donetsk fans with neo-Nazi links, whom the Sky reporters investigated for six months and filmed with hidden cameras. The Shakhtar Ultras declared readiness to target England fans during the tournament and warned black and Asian England supporters not to travel to the country for Euro 2012. Within days, newspaper articles started appearing about the report's negative effect on the families of non-white England footballers, who - like the father and brother of Theo Walcott, a mixed race English footballer - decided not to travel to Ukraine for fear of being racially abused. ${ }^{4}$ Soon the Sky video turned out to be a mere overture to another piece of investigative television journalism, the 30-minute BBC One Panorama documentary "Euro 2012: Stadiums of Hate" broadcast during prime time on 28 May 2012, eleven days before the kick-off of the championships. The reporter Chris Rogers and his team revealed shocking new evidence of racist violence and antiSemitism at the heart of Polish and Ukrainian football. The film posed two questions: one about how safe travelling was of football teams and their supporters to Poland and Ukraine, and second, whether UEFA should have chosen both nations to host the Euro in the first place. The climactic scene involved Sol Campbell, the former England footballer of Jamaican origin, with a 19-year career in the Premier League, delivering a piece of advice to the fans to stay home and watch the tournament on TV, because they "could end up coming back in a coffin."

Almost instantly a series of articles appeared in British national newspapers devoted to neo-Nazi and racist violence endangering football fans in Poland and in Ukraine. Eight dailies ran short and longer pieces on the subject in their print and several on-line editions, including The Guardian, which predicted a Euro 2012 disaster in Ukraine on its front page. ${ }^{5}$ Without exception, they all evoked the Panorama documentary as their source of evidence, in many cases the only one, not verified by any independent journalistic inquiry. Sol Campbell won fame as an expert on football-related violence in the two countries. His dramatic "coffin" warning was quoted by all newspapers over and over again for days to come and appeared in many headlines, which read like the examples below (italics added):

Sol Campbell warns England fans to avoid Euro 2012 for fear of 'coming back in a coffin'; Sol Campbell, the former England international, has warned England fans to stay away from Euro 2012 'because you could end up coming back in a coffin' 6

Campbell: Fans will go home in coffins ${ }^{7}$

Don't go to Euros. You could end up in a coffin; Sol's warning on 2012 games fans face race-hate thugs. ${ }^{8}$ 
Once the championship started on 8 June 2012, the press panic subsided, yet its key motifs regularly surfaced in the reporting throughout the tournament and maintained anxious anticipation of imminent violence, danger, aggression and racist hostility. On June 11, MailOnline stated that "[i]n eastern Europe today, ... racism is a fact of life," while the Sun recalled the "sickening scenes of racist abuse of players and a violent assault on two Asian students by neo-Nazi thugs" shown by Panorama ${ }^{10}$ and dramatically reported a mob attack on fans in Poznan in the article "'Yobs guide'; Euros alert." The quality Daily Telegraph ran a tabloid-like headline "Euro 2012: bad blood bubbles under ahead of Group A clash between co-hosts Poland and old enemy Russia" a day before the actual game (June 11) and The Times reported "fears of violence either inside or outside the stadium [that] have reached fever pitch because a march in support of Russia's Independence Day could attract the attentions of Poland's right-wing extremists." 11 A day before the England-Ukraine game in Donetsk, the Mirror evoked the scary threat of the Shakhtar Donetsk's neo-Nazi supporters that "Ukraine will become a graveyard to English fans." 12 After several days of covering the championship in this biased manner, some papers admitted that perhaps they got it wrong. "After two weeks at Euro 2012 it feels like a duty to say that most people in the Euro 2012 host countries are not stereotypes in a Panorama exposé about xenophobia," Paul Hayward wrote in the Daily Telegraph article "Panorama' exaggerated racism issue" (June 22), and the Independent on Sunday reported "anger among England fans about the way Ukraine was portrayed in the media prior to the tournament, with concerns about racism and violence most visibly aired in a BBC Panorama documentary". Those brave enough to travel to Ukraine told the paper that " $[t]$ he coverage was a disgrace. There is no violence in Ukraine and we've had an amazing welcome." ${ }^{13}$ It would require separate sociological research to establish which vision of Poland and Ukraine made a more lasting impression on the reading public.

\section{Analysis}

Three leading themes concerning the Ukrainian and Polish footballing culture emerged from close reading of the texts: pervasive football hooligan violence, vicious racism and neo-Nazism, clustered in various combinations. The topic of football hooliganism was predictable, as several authors analyzing the language and topicalization patterns of Anglophone newspaper sports reporting - particularly of mega sport events - observe the predilection for the stories and images of violence and for military metaphors (Holt 2000), narratives of fear, preoccupation with crime, as well as highlighting security and crowd control issues (Hammett 2011; Mishra 2012). However, sport media concern about neo-Nazi racism has not been reported yet and seems a new addition to the press repertoire of football-related evils. In the "post-Panorama" period the three identified themes were articulated by means of several linguistic devices contained in the 
table below and grouped into categories borrowed from Fowler (1991: 66-90) and Bednarek and Caple (2012a: 46-57).

Table 1. Most prominent linguistic tools in the British press coverage of Polish and Ukrainian football fan culture, May-June 2012

\begin{tabular}{|c|c|}
\hline Linguistic device & Examples \\
\hline $\begin{array}{l}\text { Negative overlexi- } \\
\text { calization of football } \\
\text { fans }\end{array}$ & $\begin{array}{l}\text { neo-Nazi racist thugs; Nazi thuggery; racist thuggery; race-hate } \\
\text { thugs; vicious-looking thugs; racist hooligans; racists and fas- } \\
\text { cists and anti-Semites; far-Right psychopaths; hardcore 'Ultras'; } \\
\text { violent soccer gangs; } \\
\text { a soccer hate mob; racist groups; brain-dead neo-Nazis; racist } \\
\text { Ukrainian football fans }\end{array}$ \\
\hline Negative emotivity & $\begin{array}{l}\text { horrifyingly real footage of abuse at a Ukrainian stadium; } \\
\text { shocking attacks on Asian supporters; aggressive anti-Semi- } \\
\text { tism; alarming levels of homophobia; a very dangerous place } \\
\text { [Ukraine] }\end{array}$ \\
\hline Evaluative language & $\begin{array}{l}\text { mass displays of anti-Semitism; race hate at Euro 2012; } \\
\text { the spectre of racism and neo-Nazism hangs over the host coun- } \\
\text { tries; widespread racism and anti-Semitism; a racists' haven } \\
{[\text { Poland]; the bigotry in the Ukrainian cities hosting our games; }} \\
\text { corrupt and out of control police force; selective justice }\end{array}$ \\
\hline $\begin{array}{l}\text { Action and process } \\
\text { predicates }\end{array}$ & $\begin{array}{l}\text { Yobs giving Nazi salutes, chanting anti-Semitic insults, at- } \\
\text { tacking Asian Students; Ukrainian fans making monkey nois- } \\
\text { es at black players; taunting black players; [ a Ukrainian fan }] \\
\text { punches his chest, salutes and shouts "Sieg Heil"; a far-Right } \\
\text { group in Ukraine... recruits and trains football hooligans; still } \\
\text { use racist terms against Jewish people; fans attack a small } \\
\text { group of Asian home supporters, punching and kicking them; } \\
\text { thugs who beat up the group of Indian students }\end{array}$ \\
\hline Modality: truth & $\begin{array}{l}\text { the worries about racism may prove correct; Racism is far more } \\
\text { acceptable there [in Ukraine]; } \\
\text { the situation in Poland ... is far worse; } \\
\text { fans are obviously going to be at risk; } \\
\text { the potential for targeted attacks away from the grounds is ex- } \\
\text { tremely high }\end{array}$ \\
\hline Modality: obligation & $\begin{array}{l}\text { UEFA should never have allowed Poland and Ukraine to host } \\
\text { the contest; They [Poland and Ukraine] need to sort out their } \\
\text { problems first; all England supporters should cancel their } \\
\text { flights; supporters must be careful while visiting Poland }\end{array}$ \\
\hline Presuppositions & $\begin{array}{l}\text { Poland still has a hooligan problem; ... despite the fact that rac- } \\
\text { ism is endemic in Ukraine; this combustible cauldron, where } \\
\text { racism and xenophobia appear to go unchallenged }\end{array}$ \\
\hline Metaphors & $\begin{array}{l}\text { "high risk" match; "Legia }[F C] \text { Jihad"; the former Soviet satel- } \\
\text { lite; this former Soviet republic; the EU's star pupil [Poland] }\end{array}$ \\
\hline
\end{tabular}


In addition to the examples of linguistic strategies identified above, the study sample was checked for the actual frequency of the vocabulary of violence and abuse appearing as single words and fixed lexical and/or syntactic structures. The result is the following: abuse/ racial abuse (76), attack/racist attack (40), violence (23), beat up/beating up (20), evil, offence, hate crime, insult (7). A range of violent attitudes and groups were repetitively evoked: racism (80), racist(s) (68), hooligans/ racist hooligans (17), neo-Nazis/neo-Nazism (12), the Ultras/right-wing Ultras (8) thugs, far-Right groups (7). Three most frequently reported types of unacceptable violent behaviour involve monkey chants/noises (26), Nazi salutes (8) and antiSemitic chants/insults (4). Fans planning a trip to Poland and Ukraine, especially non-white ones, were taking a risk (25), could expect fear (24), should be concerned (23), ready for danger/dangerous situations (15). The aggregation of the identified linguistic devices, typical for scare journalism, cast a dark semantic shadow on the Euro 2012 hosts by producing an excess of negative feeling towards them, put visitors' safety in doubt and diverted eager anticipation into anxiety.

The scare pattern, initially revolving around the episodes recorded by Rodgers and Campbell's urge to boycott the championship, was soon extended to incorporate a few satellite themes, the process described by Fowler as the "Pandora's box" effect (1991: 170-207). One was fear of racial abuse in the Euro 2012 countries expressed by some non-white members of the England team and their families. Second was reporting the experience of several ordinary persons without any connection with football, whose racial origin made them targets of abuse in Ukraine. Another one, observed mainly in the quality press, was making frequent references to the imprisonment and alleged mistreatment of the former Ukrainian Prime Minister Yulia Tymoshenko, convicted of embezzlement and abuse of power.

Table 2. Discursive strategies of extending football-related racism onto Polish and Ukrainian cultures in general

\begin{tabular}{|l|l|}
\hline Discursive strategy & Examples \\
\hline $\begin{array}{l}\text { References to impact } \\
\text { on individuals }\end{array}$ & $\begin{array}{l}\text { the families of black England stars Theo Walcott and Alex Ox- } \\
\text { lade-Chamberlain [are] scrapping plans to attend the tournament; } \\
\text { "I'd definitely not want my family to be there. The last thing you } \\
\text { want when you're playing is to be worrying about the safety and } \\
\text { wellbeing of your family." }\end{array}$ \\
$\begin{array}{l}\text { Mario Balotelli has added to the growing fears about racist } \\
\text { abuse during Euro 2012 by claiming he will "leave the pitch and } \\
\text { go home" if he is subjected to racism while playing for Italy dur- } \\
\text { ing next month's tournament in Poland and Ukraine. }\end{array}$ \\
\hline $\begin{array}{l}\text { Quotes from ordinary } \\
\text { people }\end{array}$ & $\begin{array}{l}\text { SHE [Ivanna Pavlovets, a journalist of Ukrainian origin] says: } \\
\text { "Racism is far more acceptable there. The Ukrainians don't see } \\
\text { it as anything too wrong. All the terms we would consider unac- } \\
\text { ceptable they still use in common parlance..." }\end{array}$ \\
\hline
\end{tabular}




\begin{tabular}{|l|l|}
\hline Discursive strategy & Examples \\
\hline $\begin{array}{l}\text { Quotes from ordinary } \\
\text { people }\end{array}$ & $\begin{array}{l}\text { He [Nigerian student Levi Nwankwo] says: 'I was escorting } \\
\text { a friend home one Sunday at about 9pm. ... We had just stepped } \\
\text { out of the door of the student hostel when suddenly five young } \\
\text { white guys appeared out of the dark and started calling us racist } \\
\text { names'. }\end{array}$ \\
'We can live well here,' he [Ivory Coast student Armel Wilfried] \\
admits. 'But the racism is very bad.' \\
\hline References individuals & $\begin{array}{l}\text { mounting concern over the treatment of the jailed opposition } \\
\text { leader Yulia Tymoshenko; opposition leader Yulia Tymoshenko } \\
\text { languishes in prison on trumped-up charges; anger over the treat- } \\
\text { ment of jailed opposition leader Yulia Tymoshenko; anger over } \\
\text { the treatment of jailed opposition leader Yulia Tymoshenko; Ya- } \\
\text { nukovych's all-consuming desire to persecute Tymoshenko }\end{array}$ \\
\hline
\end{tabular}

Thus, in the build-up to the tournament, Poland and Ukraine were constructed as generally unsafe places to visit by means of linking football-related racist behaviour with other instances of human rights abuse in the two countries. The quality press made frequent references to the unjustified imprisonment of the former Ukrainian Prime Minister Yulia Tymoshenko. The Times speculated about the "plans by some European leaders to boycott Ukraine during the tournament" over jailing her "after what many regard as a show trial." 14 The Daily Telegraph revealed in the front-page article that the hunger strike of Tymoshenko in protest to assault at the hands of prison guards caused "widespread concerns about selective justice and the rule of law in Ukraine". ${ }^{15}$ To a Ukrainian Amnesty International campaigner quoted by The Independent, the Tymoshenko case was only one of "thousands of human rights abuses visited on ordinary Ukrainians every year" and "the widespread use of torture by a corrupt and out of control police force". ${ }^{16}$ Another source of the press concern about the violation of human rights in Poland and Ukraine was the alleged intolerance of homosexuality. The Express journalist conveyed "unofficial warnings" suggesting that Ukraine was "an inadvisable destination" also for gay football fans, offering as a proof the failure of the planned first Gay Pride march in Kiev prevented by right-wing football hooligans. ${ }^{17}$ The Times went further by running a long article devoted to the "deep contempt of gay people across eastern Europe", notorious gay-bashing and the generally intolerable life of homosexual persons in those and other post-Soviet states. ${ }^{18}$

The neo-Nazi phenomenon was historicized by means of another satellite topic, that of the Holocaust in Eastern Europe during World War II. The Daily Telegraph was bemused "at the resurgence of Nazi thuggery in countries where millions were butchered by its original authors". ${ }^{19}$ Holland's captain van Bommel found the racial abuse of his black team members in Kraków disgraceful, especially in the context of their earlier visit to the Auschwitz museum, according to MailOnline and The Daily Telegraph. In a similar manner, $i$-Independent placed 
information about the planned visit of the England squad to Auschwitz and Birkenau next to the comment on their "fear of racial abuse from local fans, in the light of the BBC Panorama investigation" ${ }^{20}$ References of this kind made neoNazi hooliganism even more menacing and additionally intensified the panic.

Paradoxically, the theme of the preparations of Polish and Ukrainian police forces to secure safety and order during the tournament only fostered images of the host countries as fearsome and menacing. References appeared to "endemic police criminality [which] is going unchecked" in Ukraine, police indifference to racial violence, "no real desire to tackle the problems" and the last-minute "antidiscrimination training received by the policemen and stewards in Ukraine." The most dramatic revelations appeared on June 6 and 7 in three national dailies, all of them quoting the same editorial in the Polish local English-language paper, Krakow Post as their source.

"Poland's anti-hooligan squads are armed with: shotguns firing baton rounds that probably won't kill you as long as you're 30m away, a truck-mounted water cannon affectionately known as 'the typhoon', a high-tech sonic cannon that can make you wet yourself on its lowest setting, dogs trained to bite you directly in the testicles". ${ }^{21}$

Consequently, the prospect of being protected against incidents of violence by the police forces so brutal, malevolent and guilty of turning a blind eye to football hooliganism in the past fueled the scare stories instead of counteracting them.

The imminence of Polish football racism was intensified by reports about the Holland team being subjected to monkey chants during their training session at the stadium in Krakow, the city they chose as their Euro base. The Telegraph devoted three articles to the incident on two consecutive days and the Mail published its own report with the dramatic headline "Dutch a target of Poles' racist abuse with stars subjected to vile monkey chants" (June 7, 2012). The scale of the incident was probably quite limited, as even the Mail admitted that " $[\mathrm{N}]$ ot all the Dutch journalists heard the chanting" and failed to report it. Nevertheless, the amount of attention it received from the national dailies fueled the panic still more.

Extra credibility was added to the scary reports by giving voice to some reliable and trustworthy institutions. The official advice of the British Foreign Office for travellers of Asian and Afro-Caribbean descent and members of religious minorities to "take extra care" was quoted on a few occasions; so were the opinions of Amnesty International on civil rights abuse in Eastern Europe. On one occasion the suggestion of the US State Department was evoked that "Campbell may have a valid point". ${ }^{22}$

For the whole two weeks much journalistic effort was spent on demonstrating cultural civilization lag of Ukraine and Poland. Significantly absent from the accounts were positive references to the efforts of local institutions, organizations and armies of volunteers working with dedication towards the success of Euro in their countries. Not a single reference was found to Poland's involvement in the 
anti-racist campaign "Let's Kick Racism Out of Football" launched in 1993 by the Commission for Racial Equality and the Professional Footballers Association. Thus, while positive vibrations were sweeping across Poland and Ukraine in anticipation of the championship, fan zones were being set up in dozens of places and thousands of fans across Europe were making travel arrangements, the British media allegations poured water over the carnival atmosphere and led to a PR break-down on the eve of the tournament. Before the European footballers and their fans had a chance to experience direct contact with the Euro host societies, they became prejudiced against them by allegations of endemic racism, xenophobia and intolerance.

\section{Conclusions}

The above critical reading of the sports journalism sample raises doubts as to a possibility of squaring the ideal of sport as a unifying factor with the goals and priorities of the media, now inextricably interwoven with sport as industries and studied jointly as such (Nicholson 2006). Volumes have been written about the pressure for profit in commercial media and its influence on the quality of journalism, about the incompatibility of corporate profit and independent journalistic judgement (Bogart, 1995, 2007; Curran and Seaton 2010). In the light of this scholarship, the media cannot be expected to treat sport reporting as a form of public service or a cultural mission, as "the sport media nexus is driven by commercial forces" (Nicholson 2006: 13). The vision of violent football-related neoNazi racism in the Euro 2012 host countries had high commercial value as it fitted well within the framework of the established newsworthiness model: it was fresh and topical; it concerned a mega event, thus being of sufficient magnitude; it was culturally and geographically proximate to Britain and its press reading public; it involved football celebrities and UEFA elites. The Sky Sports and BBC Panorama programmes conveniently provided a suitable springboard for the press to discursively reinforce the news value of the tournament by foregrounding its negative sides, by intensifying the emotional appeal through personalization, and by invoking the long-lived Western stereotype of culturally inferior Eastern Europe characterized by corrupt politics, intolerance of difference, xenophobia, persecution of minorities, organized crime and disorder in the public sphere (Iordanova 1995; Maguire et al 2009; Mawby and Gisby 2009; Light and Young 2009; Korte et al 2010; Wawrzyczek et al 2010).

Yet the discussed instance of media panic fixed on drama, conflict, anomaly and deviance must not be treated as a mere construct because " $[t]$ he idea that social problems are socially constructed does not question their existence nor dismiss issues of causation, prevention and control" (Cohen 2002: xliii). Various forms of violence, racism and national chauvinism do trouble football in some stadiums of Poland, Ukraine as well as many other places in the world. The news media have every right to expose them and express moral indignation as a part of 
their role to create a well-informed citizenry aware of important social issues and occurrence of human rights abuse. Yet the use of moral-panic models to address such problems inevitably leads to imbalance and exaggeration and, consequently, becomes counterproductive in cross-cultural communication. Scary media representations discourage target audiences from engaging into contact - cognitive and/or direct - with the reported "flawed" culture, while its members, irritated by the skewed proportions in the received coverage, reciprocate distrust. Such reactions to the Panorama documentary and the press articles it inspired appeared in Poland and Ukraine in the form of diplomatic protests, voices of indignation from the institutions and individuals directly involved in the Euro and as countless blog and social media entries by the embittered public. In contrast to the opinions that hosting Euro 2012 was Poland's and Ukraine's promotional success in the eyes of the foreign media, the cultural conclusions from the present study are less optimistic. The negative visibility created for them by the British news media right before the tournament proves that mediation of intercultural contact was not on their agenda. Instead, the host nations were discursively framed in a way that made them unattractive partners for intercultural dialogue.

\section{Notes}

1 Research for this paper was supported by the grant from the National Science Centre Poland (NCN) No. 2012/05/B/HS2/04096.

2 Nick Szczepanik, "Poland and Ukraine full of eastern promise...," The Times, April 19, 2007.

3 Jim Brookes, "Poland keen to prove they are ready for Euro 2012 finals...", The Telegraph, October 10, 2011.

$4 \quad$ Matt Dickinson, "Safety fears force Walcott's family to remain at home", The Times, May 17, 2012.

5 Luke Harding, "Racism threatens to turn Ukraine's Euro 2012 into a PR disaster", The Guardian, May 29, 2012.

telegraph.co.uk, May 28, 2012.

Mike Sullivan, The Sun, May 28, 2012.

Nicola Methven, The Mirror, May 28, 2012.

9 Melanie Phillips, "The unique evil of Auschwitz and a deeply distasteful football PR stunt," MailOnline, June 11, 2012.

10 "It's time UEFA tackled racism once and for all," The Sun, June 11, 2012.

$11 \quad$ Rory Smith, "Patriotic Poles seek a modern miracle", The Times, June 11, 2012.

12 Jeremy Armstrong, "Eye predict a Rooney riot; ....", The Mirror, June 19, 2012.

13 Shaun Walker, "Three Lions fans warm to Ukraine; English supporter numbers are rising in Kiev...", June 24, 2012.

14 Damian Whitworth, " 'It's much safer to live in the closet'," June 7, 2012.

15 Martin Evans, Jason Burt, "Ministers boycott England group games at Euro 2012," June 8, 2012.

16 Neil Lancefield, “England squad set to fly to Euro 2012," Independent.co.uk, June 5, 2012.

17 Jane Warren, “The Euro football Nazis", The Express, May 29, 2012.

18 Damian Whitworth, " 'It's much safer to live in the closet'," June 7, 2012.

19 Paul Hayward, "Host governments must act or their event is in ruins;" May 30, 2012. 
20 Lawton, "Dutch a target of Poles' racist abuse...”, June 7, 2012; Jason Burt, "Dutch threat to walk off pitch over racist abuse; Captain says black players were targeted at training Incident occurred soon after squad's visit to Auschwitz", June 8, 2012.

21 Henry Winter, "Euro 2012: England hierarchy attempt to douse flames of Rio Ferdinand...," telegraph.co.uk, June 6, 2012; Daniel Taylor, "Euro 2012: Guns, dogs and water cannon - troublemakers get a warning," The Guardian, June 7, 2012; Matt Lawton, "Krakow crackdown: Hooligans fired fierce warning by police," MailOnline, June 7, 2012.

22 Jane Warren, "The Euro football Nazis", The Express, May 29, 2012.

\section{References}

Bednarek, Monika and Helen Caple (2012a) News Discourse. London and New York: Continuum. Bednarek, Monika and Helen Caple (2012b) "“Value added": Language, image and news values.' Discourse, Context and Media 1, 103-113.

Bednarek, Monika and Helen Caple (2014) 'Why do news values matter? Towards a new methodological framework for analysing news discourse in Critical Discourse Analysis and beyond.' Discourse and Society 25(2), 135-158.

Bell, Allan (1991) The Language of News Media. Oxford: Wiley-Blackwell.

Billings, Andrew C. and Marie Hardin (eds.) (2014) Routledge Handbook of Sport and New Media. Milton Park: Routledge.

Bishop, H. and A. Jaworski (2003) 'We beat 'em': nationalism and the hegemony of homogeneity in the British press reportage of Germany versus England during Euro 2000.' Discourse and Society 13, 243-271.

Bogart, Leo (1995) Commercial Culture: The Media System and the Public Interest. Oxford: Oxford University Press.

Brookes, Rod (1999) 'Newspapers and national identity: the BSE/CJD crisis and the British press.' Media, Culture and Society 21(2), 247-263.

Bruce, Toni (2004) 'Marking the boundaries of the "normal" in televised sports: the play-by-play of race.' Media, Culture and Society 26(6), 861-879.

Bruce, Toni (2015) 'Assessing the sociology of sport: On media and representations of sportswomen.' International Review for the Sociology of Sport 50, 380-384.

Ciołkiewicz, Paweł (2012) 'Euro 2012 jako przykład wydarzenia medialnego. Przyczynek do analizy' (Euro 2012 as an example of media event). Kultura i Wychowanie 4(2), 145-159.

Cohen, Stanley (1972/2002) 'Moral Panics as Cultural Politics: Introduction to the Third Edition.' In: Folk Devils and Moral Panics: The Creation of the Mods and Rockers. London and New York: Routledge, vi-xliv.

Curran, James and Jean Seaton (2010) Power Without Responsibility: Press, Broadcasting and the Internet in Britain. $7^{\text {th }}$ ed. London and New York: Routledge.

Dembek, Agata and Renata Włoch (2014) 'The Impact of a Sports Mega-Event on the International Image of a Country: The Case of Poland Hosting UEFA Euro 2012.' Perspectives 22(1), 33-47.

Dimeo, Paul and Joyce Kay (2004) 'Major sport events, image projection and the problems of 'semi-periphery': a case study of the 1996 South Asia Cricket World Cup.' Third World Quarterly 25(7) 1263-1276.

Fairclough, Norman (2010) Critical Discourse Analysis: The Critical Study of Language, $2^{\text {nd }}$ ed. London and New York: Routledge.

Fowler, Roger (1991) Language in the News: Discourse and Ideology in the Press. London and New York: Routledge, 146-207.

Galtung, Johan and Mari Holmboe Ruge (1965) 'The structure of foreign news: The presentation of the Congo, Cuba and Cyprus crises in four Norwegian newspapers.' Journal of Peace Research 2(1), 64-91. 
Garriado, Angeles Arjona, Juan Carlos Checa Olmos, Noemi Garcia-Arjona and Rodrigo Pardo (2012) 'Immigration, school, physical activity and sport. Analysis of sport acculturation in Spain.' Kinesiology 44(1), 83-93.

Gasparini, William and Aurélie Cometti (eds.) (2010) Sport facing the test of cultural diversity. Integration and intercultural dialogue in Europe: analysis and practical examples. Strasbourg: Council of Europe Publishing.

Goode, Erich and Nachman Ben-Yehuda (2009) Moral Panics: The Social Construction of Deviance, $2^{\text {nd }}$ ed. Oxford: Wiley-Blackwell.

Hammett, Daniel (2011) 'British media representations of South Africa and the 2010 FIFA World Cup.' South African Geographical Journal 93 (1), 63-74.

Harcup, Tony and Deirdre O'Neill (2001) 'What is news? Galtung and Ruge revisited.' Journalism Studies 2(2), 261-280.

Hardin, Marie, Julie Dodd, Jean Chance, Kristie Walsdorf (2004) 'Sporting Images in Black and White: Race in Newspaper Coverage of the 2000 Olympic Games.' Howard Journal of Communications 15(4), 211-227.

Holt, Ron (2000) 'The Discourse Ethics of Sports Journalism.' Culture, Sport, Society 3 (3), 88-103. Howarth, Anita (2013) 'A "Superstorm”: When Moral Panic and New Risk Discourses Converge in the Media.' Health, Risk and Society 15(8), 681-698.

Inthorn, S. (2010) 'Europe divided, or Europe united? German and British press coverage of the 2008 European Championship.' Soccer and Society 11 (6), 790-802.

Iordanova, Dina (1995/2009) 'Media Coverage of Bulgaria in the West and Its Domestic Use'. In: Fred L. Casmir (ed.) Communication in Eastern Europe: The Role of History, Culture, and Media in Contemporary Conflicts. New York and London: Routledge, 223-246

Kennedy, Peter and Christos Kassimeris (eds.) (2014) Exploring the cultural, ideological and economic legacies of Euro 2012 (Sport in the Global Society - Contemporary Perspectives). Milton Park and New York: Routledge.

Korte, Barbara, Eva Ulrike Pirker and Sissy Helff (eds.) (2010) Facing the East in the West: Images of Eastern Europe in British Literature, Film and Culture. Amsterdam and New York: Rodopi.

McGregor, Judy (2002) 'Restating News Values: Contemporary Criteria for Selecting the News.' Proceedings of the ANZCA 2002 Conference: Communication: Reconstructed for the $21^{\text {st }}$ Century. Retrieved 9 September 2016 from: http://www.anzca.net/documents/2002-conf-papers/382restating-news-values-contemporary-criteria-for-selecting-the-news-1/file.html

Neuendorf, Kimberly A. (2002) The Content Analysis Guidebook. Thousand Oaks, CA: Sage Publication.

Light, Duncan and Craig Young (2009) 'European Union enlargement, post-accession migration and imaginative geographies of the "New Europe": media discourses in Romania and the United Kingdom.' Journal of Cultural Geography 26(3), 281-303.

Maguire, Joseph, Richard Elliott, Zbigniew Mazur, Irmina Wawrzyczek (2009) 'New Europe, Old Games: Making Sense of Anglo-Polish Media Coverage of England versus Poland Football Matches.' Sport in Society 12(2), 141-155.

Marsh, Ian and Gaynor Melville (2011) 'Moral Panics and the British Media - A Look at Some Contemporary “Folk Devils".' Internet Journal of Criminology (C. www.internetjournalofcriminology.com/

Mawby, Rob C. and William Gisby (2009) 'Crime, Media and Moral Panic in an Expanding European Union.' Howard Journal of Criminal Justice 48 (1), 37-51.

Mazur, Zbigniew and Irmina Wawrzyczek (2016) 'Interculturality and sport: mediatization of culture contact in reporting Euro 2012 by the British and Irish national press.' Artes Humanae 1(1), $147-162$.

Merkel, Udo (2014) 'German football culture in the new millennium: ethnic diversity, flair and youth on and off the pitch.' Soccer and Society 15(2), 241-255.

Mishra, Suman (2012) "The Shame Games": a textual analysis of Western press coverage of the Commonwealth Games in India.' Third World Quarterly 33(5), 871-886. 
Molek-Kozakowska, Katarzyna and Jan Chovanec (2017-forthc.) 'Media representations of the 'other" Europeans: Common themes and points of divergence'. In: Chovanec, Jan and Katarzyna Molek-Kozakowska (eds.). Representing the Other in European Media Discourses. Amsterdam and Philadelphia: John Benjamins, 1-22.

Müller, Floris, Lisbet van Zoonen and Laurens de Roode (2008) 'The integrative power of sport: Imagined and real effects of sport events on multicultural integration.' Sociology of Sport Journal 25(3), 387-401.

Nicholson, Matthew, Anthony Kerr and Merryn Sherwood (2007/2015) Sport and the Media: Managing the Nexus, Second Edition. London and New York: Routledge, Part 1.

Raney, Arthur A. (ed.) (2006) Handbook of Sports and Media. Mahwah, NJ: Erlbaum.

Riffe, Daniel, Stephen Lacy and Frederick Fico (2014) Analysing Media Messages: Using Quantitative Content Analysis in Research, $3^{\text {rd }}$ ed. New York: Routledge.

Rosner, Jennifer, Li Yanmei, Melody Manchi Chao and Hong Ying-yi Hong (2010) 'One world, just a dream? Effects of the Beijing Olympic icon on perceived differences between Eastern and Western culture.' Asian Journal of Social Psychology 13(2), 139-151.

'Sharing Diversity: National Approaches to Intercultural Dialogue in Europe. Study for the European Commission' (2008). Report of the European Institute for Comparative Cultural Research, X-XI. Retrieved 09 April 2016 from http://www.interculturaldialogue.eu/web/files/14/en/ Sharing_Diversity_Final_Report.pdf.

Shoemaker, Pamela J. and Akiba A. Cohen (2006) News Around the World: Content, Practitioners, and the Public. New York and London: Routledge.

Schulz, W.F. (1982) 'News structure and people's awareness of political events.' International Communication Gazette 30(3), 139-153.

'Ukraine's Hidden Hooligans' (2012) Special Report, Part 1 and 2. Sky Sports, 13.05. http://www. skysports.com/football/news/20438/7758043/ukraines-hooligans. Retrieved 11 April 2016.

Van Dijk, Teun A. (1988) 'The Tamil panic in the press.' In: Teun A. van Dijk, News Analysis: Case Studies of International and National News in the Press. Hillsdale, NJ: Erlbaum, 215-254.

Van Dijk, Teun A (2001) 'Critical Discourse Analysis.' In: Tannen, Deborah, Deborah Schiffrin and Heidi Hamilton (eds.) Handbook of Discourse Analysis. Oxford: Blackwell, 352-371.

Van Leeuwen, Theo (2008) Discourse and Practice: New Tools for Critical Discourse Analysis. Cambridge: Cambridge University Press.

von der Lippe, Gerd, Malcolm MacLean (2008) 'Brawling in Berne: Mediated transnational moral panics in the 1954 Football World Cup.' International Review for the Sociology of Sport 43(1), 71-90.

Watson, Matthew R. (2013) 'The Dark Heart of Eastern Europe: Applying the British model to football-related violence and racism.' Emory International Law Review 27, 1055-1104.

Wawrzyczek, Irmina, Zbigniew Mazur, Hanna Szewczyk and Alan Bairner (2010) Oswajanie Innego. Obraz Polski i Polaków w prasie brytyjskiej w latach 2002-2007 (Taming the Other: Poland and the Poles in the British press 2002-2007). Lublin: Gaudium.

Wenner, Lawrence (ed.) (1998) Media Sport. London and New York: Routledge.

Wensing, Emma H., Toni Bruce (2003) 'Bending the rules: Media representations of gender during an international sporting event.' International Review for the Sociology of Sport 38(4), 387-396.

White Paper on Intercultural Dialogue 'Living Together As Equals in Dignity' (2008). Strasbourg: Council of Europe.

Wizor, Michał (2012) 'Sport, medialność, pieniądze, prestiż - dlaczego EURO 2012 może stanowić potencjalnie atrakcyjny cel dla terrorystów?' (Sport, mediality, money, prestige - Euro 2012 as a potentially attractive target for terrorists). Spoleczeństwo i Polityka 2 (31), 163-176.

Wodak, Ruth and Michael Meyer (eds.) (2006) Methods of Critical Discourse Analysis. London: Sage. 
Irmina WaWrzycZeK Ph.D., is professor of Anglo-American cultural studies at the Maria CurieSkłodowska University in Lublin, Poland. Her academic work focuses mainly on the cultural analysis of the media in English, with special interest in the relationship between mediated sports, national identities and interculturality.

Address: Irmina Wawrzyczek, Department of English, Maria Curie-Skłodowska Univertsity, Pl. Marii Curie-Skłodowskiej 5, 20-031 Lublin, Poland. [e-mail: irmina@hektor.umcs.lublin.pl] 
